\title{
$1 \quad$ Litterfall and growth in three forests in Montseny massif
}

2 Antònia Caritat*, Marina Pi, Lluís Vilar and Jordi Bou

3 Grup Flora i Vegetació, Facultat de Ciències, Universitat de Girona, Campus Montilivi, 417071 Girona.

$5 \quad$ *antonia.caritat@udg.edu

6

7

8

9

10

11

12 Characters: 20.343

13 Figures : 5

14 Tables: 3

15

16

17

18

19

20

21 
ABSTRACT

23

The nemoral forests of the montane level are especially interesting, because they are on the edge of their distribution. We want to see the influence of some environmental conditions (temperature and rainfall) on the litterfall and growth, in three kinds of these forests. The Montseny massif in the NE part of Iberian Peninsula, with a maximum altitude of $1.706 \mathrm{~m}$, has a strong gradient of climate and vegetation, from the lowlands to the top of the mountains. We analyze three forests in the Montseny massif, two of them are composed by deciduous species not very extensive in the region (beech and sessile oak) and the other is a Mediterranean species, the mountain holm oak. We recollect data since 2007, monthly litterfall was measured and radial growth, and correlated with the climate of the study area. Our results shows that Fagus sylvatica recorded the biggest drop in annual litterfall (6.3 $\mathrm{Mg} / \mathrm{ha}$ ), followed by $Q$. ilex (5.3 Mg / ha) and Q. petraea (4.6 Mg / ha) all recorded values are similar to those observed in other forests and mountains of the same state of maturity equivalent. The start of the growth took place in the spring and Quercus spp. occurred more gradually than in F. sylvatica. We found that the accumulated rainfall in late spring has had a positive effect specially on the growth of Quercus species while the effect of summer temperature has been especially prominent in beech. Mediterranean species show larger fluctuations growth than Central European ones in response to lower water availability.

Keywords: radial growth, litterfall, Fagus sylvatica, Quercus ilex, Quercus petraea, response to climatic variables 


\section{Introduction}

Numerous mountain areas in the Iberian Peninsula are susceptible to the effects of climate change and some have been affected by recent summer droughts. In forests, the most serious effects are detected at the southernmost limits of the ranges of trees such as Fagus sylvatica L. (Fotelli et al., 2009) and Quercus petraea Matt. Lieb (Aranda et al., 2000). The effects of climate change could prompt species to move to higher altitudes (Peñuelas and Boada, 2003) or provoke the replacement of deciduous species by evergreen Mediterranean species - above all, Quercus ilex - that are more resistant to prolonged dry summers. On the other hand, the observed increase in the efficiency of water use in populations of beech in the Iberian Peninsula located in low-lying areas (Jump et al, 2006) that have been subject to intense heat in recent last decades (Peñuelas et al., 2008) demonstrates this species' ability to deal with some of the requirements arising from this new climatic situation.

Thus, in the context of climate change, it is important to know how the most vulnerable species that are located on the edge of their distribution respond to climate variation, and to compare their response with that occurring in species such as $Q$. ilex that have mechanisms that allow them to adapt to the increased water stress that are typical of the Mediterranean region. We want to know the response of the three tree species to the meteorological data in Montseny massif as a representative area of mountains of north east of Iberian Peninsula in order to relate with climatic change.

\section{Material and methods}

At the end of spring 2006 three experimental beech plots of $400 \mathrm{~m}^{2}$ were defined at Coll de Te, while in the sessile and holm oak forest at Marmolers in autumn 2006 three circular plots with a radius of $10 \mathrm{~m}$ were defined in each forest type. In each experimental plot forest and floristic parameters were evaluated (Table 1). In summer 2006, five litter traps covering an area of $0.25 \mathrm{~m}^{2}$ were installed in the Coll de Te beech forest and in the sessile and holm oak forest at Marmolers.

To study tree growth, in May 2007 we placed a dendrometer band (Fig. 1) on five trees over $10 \mathrm{~cm}$ selected in each plot in the beech forest to monitor monthly the trees' radial growth. The dendrometers were placed on the oak trees following the same guidelines in early June 2007. In 2008 we installed three electronic dendrometers in the 
beech and oak forests in order to record the continuous growth of the different tree types. Data were recorded in every month.

During autumn 2008 at Marmolers forest was cleared for firewood, which meant that all the traps and dendrometers had to be removed. They were subsequently reinstalled to conduct a new inventory of the tree layer.

The differences in annual growth were obtained using an analysis of variance (one-way ANOVA) in which the factor considered was the year. This analysis was conducted in order to compare the response of these variables to dry and wet years.

Prior to the statistical analysis the Shapiro-Wilk test was applied to test for normality. Where necessary, the initial data was transformed to reach a normal distribution. In case of significant differences in the ANOVA and/or if the data did not meet the assumption of heteroscedasticity, post-hoc tests (Tukey HSD if data were homoscedastic and Games-Howell if heteroscedastic) were employed in order to determine significant differences between years.

The effect of meteorological variables on the production of total litterfall and leaf growth, and the increase in basal area (BAI) was studied monthly using a Pearson linear correlation. Meteorological data came from the Viladrau meteorological station (451837X, 4632388Y)

\section{Results}

\section{Composition of the litterfall}

The data obtained show that the annual litterfall production was greatest in $F$. sylvatica $(6.3 \mathrm{Mg} / \mathrm{ha})$, followed by $Q$. petraea $(5.3 \mathrm{Mg} / \mathrm{ha})$ and $Q$. ilex $(4.6 \mathrm{Mg} / \mathrm{ha})$. Holm oak leaves represented $66.52 \% \pm 6.38 \%$ of the total litterfall, while in the deciduous species the leaf litterfall fraction had values of $73 \% \pm 9.81 \%$ in $Q$. petraea and $72.31 \% \pm 4.74 \%$ in F. sylvatica. The observed percentage for fruit in the litterfall in the oak woods was $8 \%$ but about $14 \%$ in the beech and holm oak forests.

Figure 2 shows the monthly variations in litterfall for the deciduous species. The main peaks are due to leaf fall and usually occur in October or November. Since 2009 maximum leaf fall in Fagus sylvatica has occurred just before Quercus petraea. There were two other remarkable peaks, one in September 2008 and the other in May 2009 
In the mountain holm oak forest, however, there are two main peaks in the intrayear litterfall curve (Fig. 3). The first takes place in the spring, in May-June, and the second usually in November

The second peak in the intra-year litterfall occurs in large part due to leaf fall in $Q$. petraea.

\section{9}

\section{Radial growth}

Figure 4 illustrates the acquired radial growth patterns in the three different species during the study period. The main radial growth period is usually restricted to spring, best seen in Quercus ilex and Fagus sylvatica. In addition to the spring peak, a second growth peak usually occurs in autumn.

Positive correlations were observed between radial growth and rainfall in JuneJuly in the oak species (that were significant in $Q$. petraea); nevertheless, in the beech the positive correlation occurred in August (Table 3).

In terms of spring and autumn average temperatures, there was a positive but not significant effect on radial growth in $F$. sylvatica. In summer for $Q$. petraea, radial growth correlates negatively with maximum temperature in June-July. In the case of beech, radial growth is negatively and significantly correlated with maximum temperatures in August.

In addition, it is also worth noting that in deciduous species two opposing tendencies were observed in the annual increase of $\mathrm{AB}$ (Fig. 5): although the annual increase is getting smaller in F. sylvatica, it is getting greater in $Q$. petraea every year. However, this trend was reversed in 2011 and the increase in AB was greater compared to the previous year in both species.

\section{Discussion}

\section{Composition and phenology of the litterfall}

In almost all cases, the values for litterfall production were similar to those observed in other forests and mountains with similar degrees of maturity; the exception 
were the beech forests, in which there was a slightly greater drop in annual litterfall, possibly because the studied beech forest is more mature (Rodà et al., 1999; Verdú, 1984). In all cases, leaves compose the bulk of the litterfall fraction, as has been shown by other studies (Carceller et al., 1989 Rapp et al., 1999; Santa Regina, 1987).

In studies of beech forests in different successional states, Lebret et al. (2001) conclude that the total percentage of leaf litterfall in mature beech forests is around $70 \%$, values that match the results of this study and other studies in mature beech forests (Santa Regina et al., 1999).

In a study conducted on 10 different species of trees in very mature woods, Kira and Shide (1967) report that the leaf fraction tends to represent about $50 \%$ of the total litterfall. In the $Q$. ilex forest, the fruit percentage was slightly higher than that found by Bellot et al. (1992) (6.3\%) in the Prades holm oak forest (NE Spain), probably because of the more northern situation of the Montseny Massif and its more humid and stable climate than Prades. Nevertheless, apart from the influence of weather conditions, we should also take into account the great inter-annual variability in fruit production in the studied species, since years of abundance are often followed by years of low production. Both F. sylvatica and Q. petraea (Fig. 2) had a seasonal pattern in their monthly foliar litterfall, which is consistent with the typical pattern of leaf fall in deciduous species (Verdú et al., 1984; Witkamp and Van der Drift, 1961) in cold and temperate regions in the northern hemisphere, where peak leaf fall occurs in autumn. However, the species differ in the month of maximum leaf fall, which occurs normally in November in the $Q$. petraea forests but varies in $F$. sylvatica forests according to the year. This is due to the fact that the beech is more sensitive to climatic conditions.

In the mountain holm oak forest, however, there are two peaks in the intra-year litterfall (Fig. 3). The first takes place in the spring in May and June after the first sprouting and is common in Mediterranean species (Caritat et al., 1996). This leaf fall is interpreted to be an adaptation by $Q$. ilex to the Mediterranean climate and its summer drought, and an attempt by trees to minimize water loss through transpiration during the period of greatest stress (Escudero et al. 1987). The second peak in the intra-year litterfall occurs in large part due to leaf fall in $Q$. petraea. As various authors have observed in other Mediterranean forests (Leonardi et al., 1992; Bussoti et al., 2003; Caritat et al., 2006), a second leaf fall may occur in October and November. This autumn leaf fall in Mediterranean evergreen species is related to a secondary sprouting 
177 that follows the summer drought and comes before the arrival of the winter frosts if weather conditions are favourable (i.e. rainfall in September and October) Bellot et al. (1992).

In addition, we observed that in relation to the two peaks in leaf fall, evergreen species decline more gradually than deciduous species. The cost of producing evergreen leaves is higher than that of deciduous leaves due to the greater concentration of lignin (Aerts, 1995). Thus, the higher production costs of evergreen leaves ensure that they are preserved for longer than in deciduous trees.

\section{Influence of meteorological variables on litterfall.}

For Quercus spp., falling $Q$. ilex leaves in spring correlated negatively with rainfall (Table 2) since a priori the lack of precipitation favours leaf fall. This is interpreted as an adaptation by this species to water deficit since leaf fall reduces water loss through transpiration during summer drought. Also in El Montseny, in the evergreen $Q$. suber forest at Polell, there was a positive correlation between litterfall and temperature as warmer years had greater litterfall (Caritat et al. 2006).

Furthermore, when there is greater rainfall, more leaf fall occurs in deciduous trees (although values were not statistically significant). Increased rainfall encourages more intense sprouting and an increase in leaf production. In the case of $F$. sylvatica, leaf fall in autumn correlates negatively with temperature, thereby demonstrating this tree's sensitivity to high temperatures. These results are similar to those obtained by Gloaguen and Touffet (1982). To verify these trends a longer-term study of litterfall in these forests in relation to climate variables would be necessary.

\section{Influence of meteorological variables on radial growth.}

Radial growth in the Mediterranean is usually restricted to spring and part of autumn, when rainfall is most abundant and temperatures are moderate (Montserrat Martin et al., 2009). The F. sylvatica growth pattern was the most consistent during the study period and the maximum growth peak was found to occurs usually in June and July.

As mentioned above, in addition to the spring peak, a second growth peak usually occurs in autumn, which is much less important and shorter than in spring and related to favourable weather conditions (i.e. heavy rainfall and no freezing temperatures). In our 
case, positive correlations were observed between radial growth and rainfall in June-

211 July in the oak trees, whereas in beech the positive correlation was in August (Table 3).

212 This may explain why $Q$. petraea and $Q$. ilex grow on dry slopes where the soil can

213 retain more moisture in rainy springs. F. sylvatica, on the other hand, lives in an area

214 that is regularly wet in spring and so steady growth every year is possible; nevertheless,

215 it does still suffer in August in dry summers. Our results therefore are consistent with

216 those found in temperate forests in Italy (Nola 1991), in which there is also a positive

217 correlation between summer precipitation and radial growth.

218 In terms of spring and autumn temperatures, there is a positive effect on radial 219 growth in F. sylvatica as it grows in relatively wet sites. In northern Spain, Pérez (1993)

220 also found a positive effect for spring temperature in $Q$. robur and $Q$. petraea. In the

221 case of beech, temperature in August is negatively correlated with radial growth since too-high temperatures inhibit tree growth, as reported by Gutierrez (1988).

\section{Conclusions}

The drop in annual litterfall in the studied forests is similar to that observed in other studies in the Montseny massif and in other European forests. The litterfall phenology of all three studied species resembles the typical patterns described in the temperate forests of the northern hemisphere.

In $Q$. ilex the observed links between leaf fall and climatic variables was as would be expected in a typical Mediterranean species, in which low rainfall and high temperatures favour leaf fall in spring. In deciduous species, however, the opposite is true, above all in $F$. sylvatica.

The pattern of annual radial growth or basal area was fairly even throughout the study period, especially in the case of $F$. sylvatica, and the largest increases occurred in June and July. The Quercus spp. species were highly sensitive to water availability in early summer. The radial growth of $Q$. petraea correlated positively and significantly with rainfall in June and July. Moreover, the special sensitivity of $F$. sylvatica to high temperatures was made evident by the significant negative effect of the average maximum temperature on growth in August.

In $F$. sylvatica there was a reduction in the average annual increase of the basal area for three consecutive years that could be explained by the climatic conditions in specific years of the study period, and which, overall, could be attributed to temperature 
trends at work in El Montseny in recent years. This growth enables us to predict that under current climatic conditions, with an increase in temperature following the tendencies detected in El Montseny, F. sylvatica will move to higher levels where thermal conditions are more suitable. In addition, it will probably be replaced at lower levels by Mediterranean species such as Quercus ilex that possess more mechanisms for dealing with fluctuations in water availability and have greater resilience to higher temperatures.

Overall, in the context of climate change, differential responses to meteorological conditions in the forest species studied need to be taken into consideration in the conservation and evolution towards maturity of these forest ecosystems.

\section{Acknowledgements}

This study was made possible by the Diputació de Girona. We are thankful to the rangers of the Diputació de Barcelona, Dr Santi Sabaté of the University of Barcelona and everyone else who helped obtain the results.

\section{References}

Aerts R, 1995. The advantages of being evergreen. Trends Ecol. Evol. 10:402-407.

Aranda I, Gil L, Pardos JA, 2000. Water relations and gas exchange in Fagus sylvatica and Q.petraea in a mixed stand at their southern limit of distribution in Europe. Trees 14: 344-352. doi:10.1007/s004680050229

Bellot J, Sánchez JR, Lledó MJ, Martínez P, Escarré A, 1992. Litterfall as a measure of primary production in Mediterranean holm oak forest. Vegetatio 99-100: 69-76. doi:10.1007/BF00118211

Bussotti F, Borghini F, Celesti C, Leonzio C, Cozzi A, Bettini D, Ferretti M, 2003. Leaf shedding, crown condition and element return in two mixed holm oak forests in Tuscany, central Italy. Forest Ecol. Manage. 176: 273-285.

Carceller F, Santa Cecilia MA, Vallejo VR, Novo M, 1989. Introduction to organic material in five forest ecosystems of Moncayo - Turiaso, 9: 361-372.

Caritat A, Bertoni M, Molinas M, Oliva M, Dominguez A, 1996. Litterfall and mineral return within cork-oak forest. Annales des Sciences Forestières, 53,1049-1058 
Caritat A, García-Berthou E, Lapeña R, Vilar L, 2006. Litter production in a Quercus suber forest of Montseny (NE Spain) and its relationship to meteorological conditions. Annals of Forest Science 63(7): 791-800.doi: 10.1051/forest:2006061

Escudero A, Del Arco JM, 1987. Ecological significance of the phenology of leaf abscission, Oikos, 49: 11-14.

Fotelli MN, Nahmn M, Radoglou K, Rennenberg H, Halyvopoulos G, Matzarakis A, 2009. Seasonal and interannual ecophysiological responses of beech (Fagus sylvatica) at its south-eastern distribution limit in Europe. Forest Ecology and Management, 257: 1157-1164.

Gloaguen JC, Touffet J, 1982. Litter production in oak-beech atlantic forest. Relations with climatic characteristics - Rev. For. Fr. 34: 108-118.

Gutiérrez E, 1988. Dendroecological study of Fagus sylvatica L. in the Montseny Mountains (Spain). Acta Oecologica - Oecologia Plantarum, 9:301-309.

Kira T, Shidei T, 1967. Primary production and turnover of organic matter in different forest ecosystems of the Western Pacific. Jpn. J. Ecol. 17:70--87.

Jump AS, Hunt JM, Peñuelas J, 2006. Rapid climate change related growth decline at the southern range edge of Fagus sylvatica. Global Change Biology 12: 21632174. doi:10.1111/j.1365-2486.2006.01250.x

Lebret M, Nys C, Forgeard F, 2001. Litter production in an Atlantic beech (Fagus sylvatica L.) time sequence. Annals of Forest Science, 58(7): 755-768

Leonardi S; Rapp M; Failla M, Komaromy E, 1992. Biomasse, minéralomasse, productivité et gestion de certains elements biogènes dans une forêt de Quercus suber L. en Sicile (Italie). Ecologia Mediterranea 18: 89-98.

Montserrat-Martí G, Camarero JJ, Palacio S, Pérez-Rontomé C, Milla R, Albuixech J, Maestro M, 2009. Summer-drought constrains the phenology and growth of two co-existing Mediterranean oaks with contrasting leaf ha- bit». Trees, vol. 23, núm. 4:787-799. 10.1007/s00468-009-0320-5

Nola P, 1991. Primo approcio alla dendroclimatologia della quercia (Quercus robur L.) e Quercus petraea ((Mattuschka) Liebl.) in pianura padana (Italia settentrionale). Dendrochronologia 9: 71-94.

Peñuelas J, Boada M, 2003. A global change-induced biome shift in the Montseny mountains (NE Spain). Global Change Biology 9: 131-140. doi: 10.1046/j.13652486.2003.00566.x 
Peñuelas J, Ogaya R, Hunt JM, Jump AS, 2008. 20th century changes of tree-ring d13C at the southern range-edge of Fagus sylvatica. Increasing water-use efficiency does not avoid the growth decline induced by warming at low altitudes. 14:10761088.

Pérez-Antelo A, 1993. Dendrocronología de Quercus petraea (Mattuschka) Liebl., Q. pyrenaica Willd., $Q$. robur L., sus nothotaxones y Castanea sativa Miller en Galicia (España). PhD Thesis. Universidad Autónoma de Madrid, Spain.

Rapp M, Santa Regina I, Rico M, Gallego HA, 1999. Biomass, nutrient content, litterfall and nutrient return to the soil in Mediterranean oak forests. Forest Ecology and Management 119: 39-49.

Rodà F, Retana J, Gracia CA, Bellot J, 1999. Ecology of Mediterranean Evergreen Oak Forests. Ecological Studies 137. Springer ISBN 978-3-642-58618-7

Santa Regina I, 1987. Contribución al estudio de la dinámica de la materia orgánica y bioelementos en bosques en la Sierra de Béjar. Tesis Doctoral. Universidad de Salamanca. Salamanca, España.

Santa Regina I, Tarazona T, 1999. Orgànic matter dynamics in beech and pine stands of mountainous Mediterranean climate area Annals of Forest Science, vol.56, núm. 8: 667-677.

Verdú AMC, 1984. Circulació de nutrients en ecosistemes forestals del Montseny: caiguda de virosta i descomposició de les fulles. Tesi doctoral. Bellaterra: Universitat Autònoma de Barcelona.

Witkamp M, Van der Drift J, 1961. Breakdown of forest litter in relation to environmental factors, Plant and Soil, vol,15, núm 4:295-311. 
331 Table 1: Characteristics of the three studied forests

\begin{tabular}{cccc}
\hline & Fagus sylvatica & Quercus petraea & Quercus ilex \\
\hline UTM & $456102 X, 4626901 Y$ & $457180 X, 4627004 Y$ & $457206 \mathrm{X}, 4627098 \mathrm{Y}$ \\
\hline Altitude(ma.m.s.l.) & 1000 & 850 & 850 \\
\hline Orientation & East & South-east & South-east \\
\hline Slope & $23-29 \%$ & $18-21 \%$ & $24-28 \%$ \\
\hline Substratum & Granodiorite & Granodiorite & Granodiorite \\
\hline Soil depth & $>40 \mathrm{~cm}$ & $24-32 \mathrm{~cm}$ & $22-30 \mathrm{~cm}$ \\
\hline Tree level & F. sylvatica $100 \%$ & Q. petraea $93 \%$ & Q. ilex $75 \%$ \\
\cline { 2 - 4 } & & Castanea sativa7\% & Q. petraea $25 \%$ \\
\hline Density n/ha & $408 \pm 38$ & $2601 \pm 32$ & $732 \pm 32$ \\
\hline Biomass Mg/ha & $237 \pm 38$ & $217 \pm 9$ & $76 \pm 25$ \\
\hline
\end{tabular}

333

334 
335 Table 2: Pearson coefficient between spring weather variables of precipitation and 336 temperature, and the leaves fraction and total litterfall of Q.ilex, Q.petraea and 337 F.sylvatica during Spring or Autum).

\begin{tabular}{ccccc}
\hline \hline \multirow{2}{*}{$\begin{array}{c}\text { Forestry } \\
\text { variable }\end{array}$} & \multirow{2}{*}{$\begin{array}{c}\text { Sp period } \\
\text { data }\end{array}$} & Sp & \multicolumn{2}{c}{ Spring } \\
\cline { 3 - 5 } Total litterfall & Spring & Q. ilex & 0,14 & $-0,959^{* *}$ \\
\cline { 2 - 5 } & \multirow{2}{*}{ Autum } & F.sylvativa & $-0,442$ & 0,272 \\
\cline { 3 - 5 } & Spring & Q.petraea & 0,388 & 0,643 \\
\cline { 2 - 5 } Leaves & \multirow{2}{*}{ Autum } & F.sylvativa & $-0,531$ & 0,348 \\
\cline { 3 - 5 } & & Q.petraea & 0,594 & 0,653 \\
\hline \hline
\end{tabular}

$* *$ p-value $<$
0,01

339

340 
341 Table 3: Pearson correlation between Basal Area Increment (BAI) of F. sylvatica, Q.

342 petraea and $\mathrm{Q}$. ilex, and the variables of average temperature $(\mathrm{T})$, highest average

343 temperature (Tmax) and precipitation $(\mathrm{P})$.

\begin{tabular}{|c|c|c|c|c|}
\hline \multirow[b]{2}{*}{$\begin{array}{l}\text { Weather } \\
\text { variable }\end{array}$} & \multirow{2}{*}{$\begin{array}{l}\text { Year } \\
\text { period }\end{array}$} & \multicolumn{3}{|c|}{ Basal Area Increment (BAI) } \\
\hline & & $\begin{array}{c}F . \\
\text { sylvatica }\end{array}$ & $\begin{array}{c}Q . \\
\text { petraea }\end{array}$ & $\begin{array}{c}Q . \\
\text { ilex }\end{array}$ \\
\hline \multirow{4}{*}{$\mathrm{T}$} & APR-MAY & 0,569 & 0,135 & $\begin{array}{c}- \\
0,002\end{array}$ \\
\hline & JUN-JUL & 0,073 & $-0,841$ & $\begin{array}{c}- \\
0,575 \\
\end{array}$ \\
\hline & AUG & $-0,726$ & 0,32 & $\begin{array}{c}- \\
0,054\end{array}$ \\
\hline & SEP-NOV & 0,511 & 0,127 & 0,187 \\
\hline \multirow{4}{*}{ Tmax } & APR-MAY & 0,798 & 0,356 & 0,166 \\
\hline & JUN-JUL & $-0,139$ & $-0,747$ & $\begin{array}{c}- \\
0,572 \\
\end{array}$ \\
\hline & AUG & $-0,832 *$ & 0,454 & $\begin{array}{c}- \\
0,098\end{array}$ \\
\hline & SEP-NOV & 0,069 & 0,534 & $\begin{array}{c}- \\
0,445 \\
\end{array}$ \\
\hline \multirow{4}{*}{$\mathrm{P}$} & APR-MAY & $-0,804$ & $-0,357$ & $\begin{array}{c}- \\
0,139\end{array}$ \\
\hline & JUN-JUL & $-0,102$ & $0,881 *$ & 0,649 \\
\hline & AUG & 0,729 & $-0,233$ & 0,144 \\
\hline & SEP-NOV & 0,437 & $-0,191$ & 0,449 \\
\hline
\end{tabular}


347

Figure 1: Beech tree at Coll de Te with dendrometers

348

349

350

351

352

353

354

355

356

357

358

359

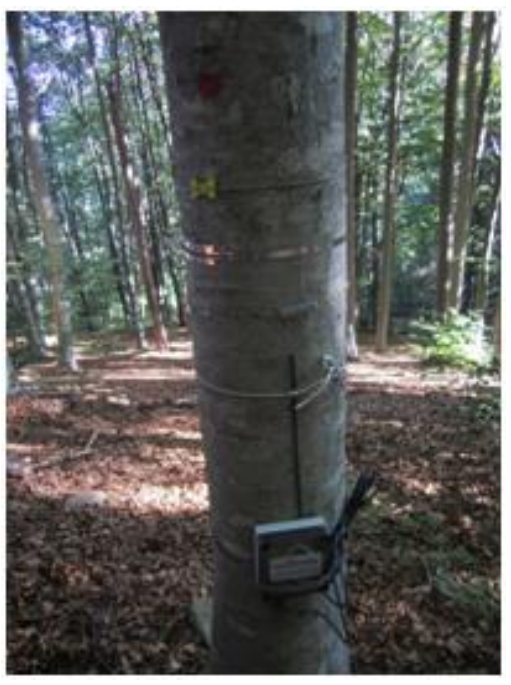


360 Figure 2: Monthly litterfall registered in the Coll de Te beech wood and in the oak 361 forest at Marmolers

362

363

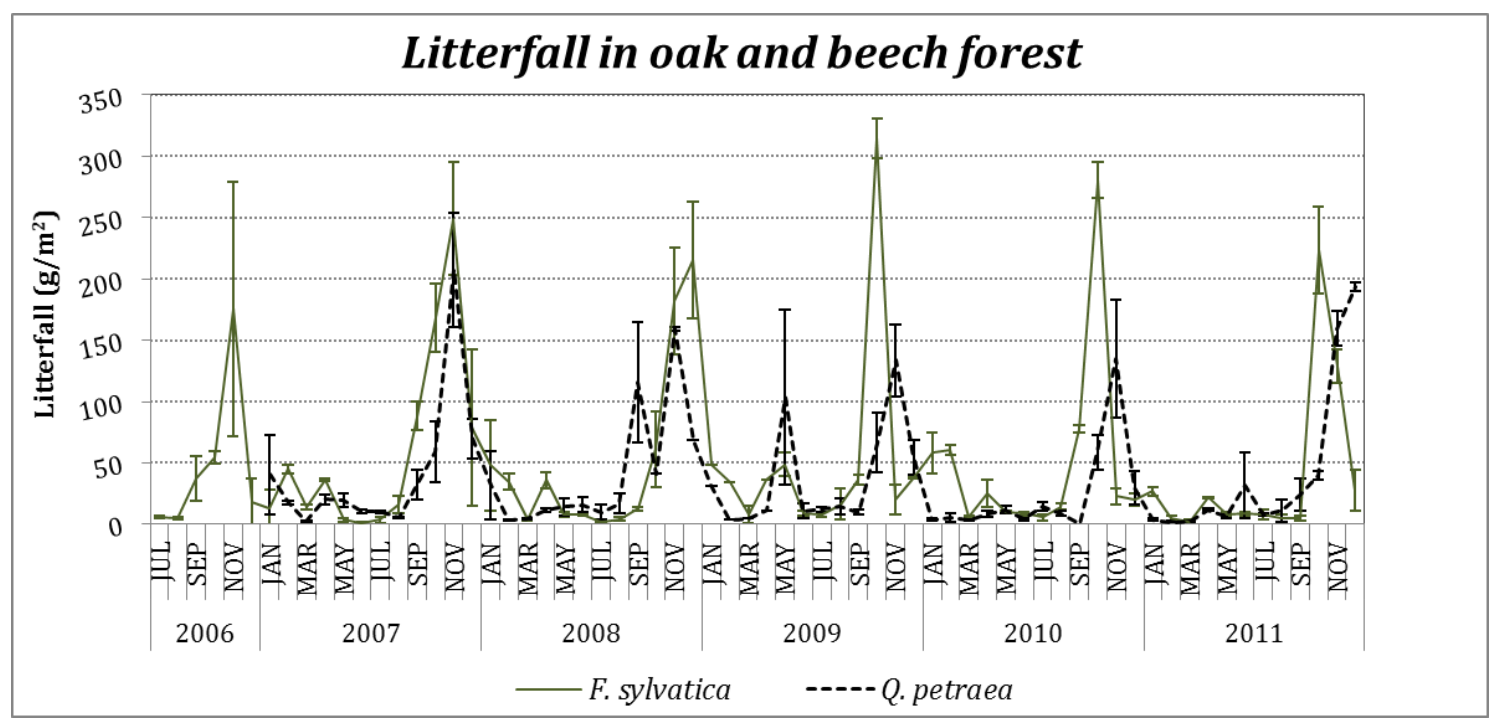

364 
365

366

367

368

369

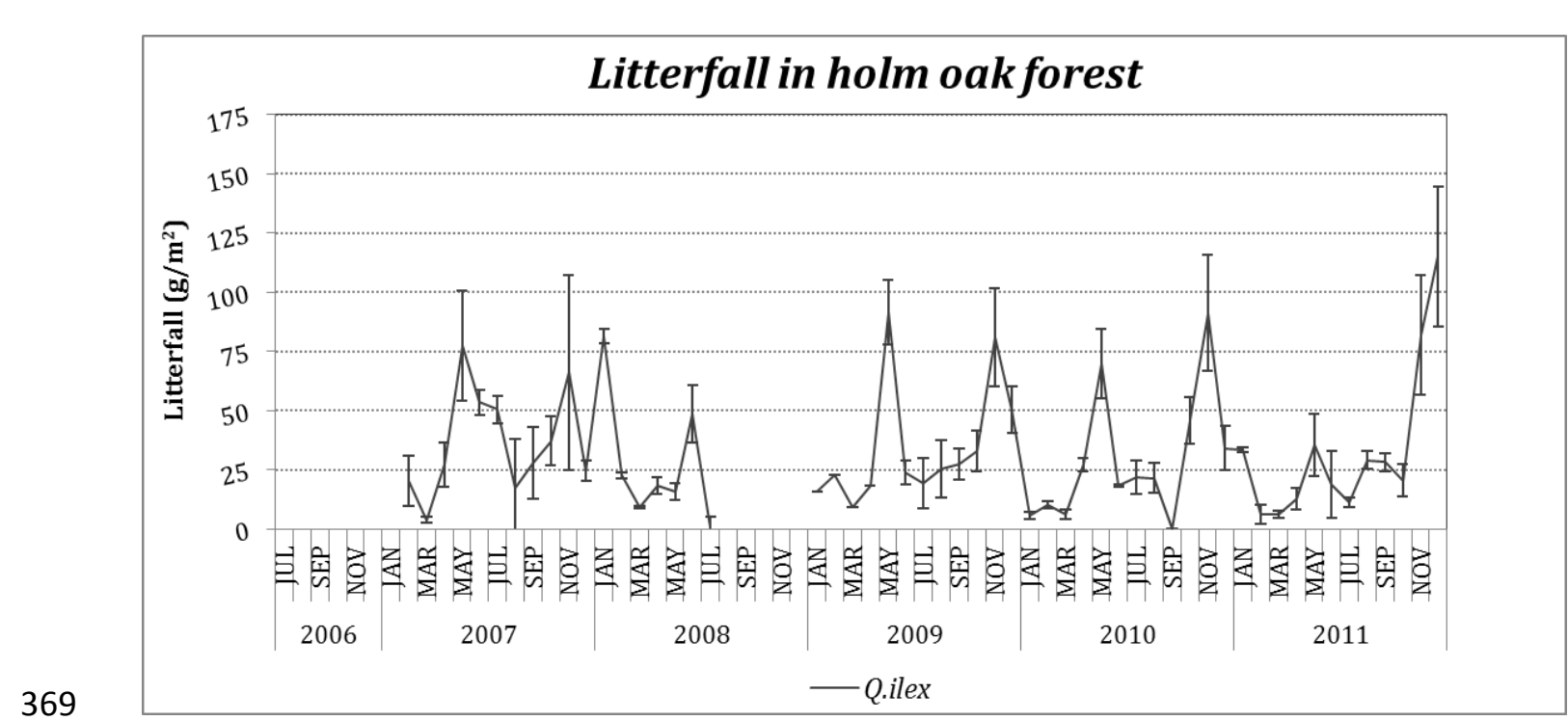

Figure 3: Monthly total litterfall recorded in the holm oak forest at Marmolers. The bars correspond to the standard deviation (SD). There were no data for the second half of 2008. 
371 Figure 4: Record of the cumulative radial growth (Basal Area Increment - BAI) at the

372 Marmolers sessile (A) and holm (B) oak forests, and Coll de Te beech forest (C).
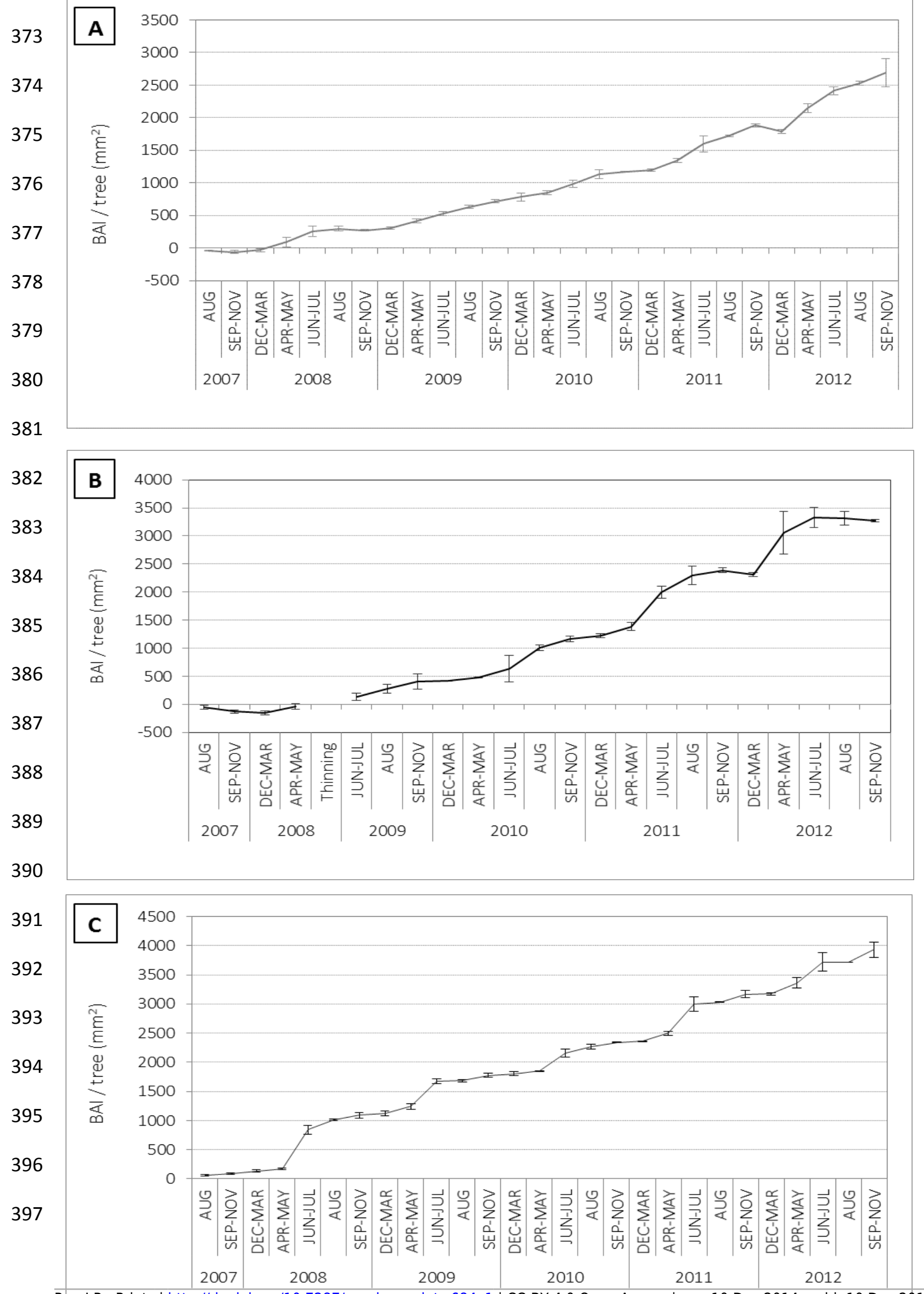

Peerj PrePrints | http://dx.doi.org/10.7287/peerj.preprints.684v1 | CC-BY 4.0 Open Access | rec: 10 Dec 2014, publ: 10 Dec 2014 
398

399

400

401

402

403

404

405

406

407
Figure 5: Annual increase in basal area (BAI) expressed in $\mathrm{mm} 2$ during the period August-July (of the following year). Bars: standard deviation plots ( \pm SD)

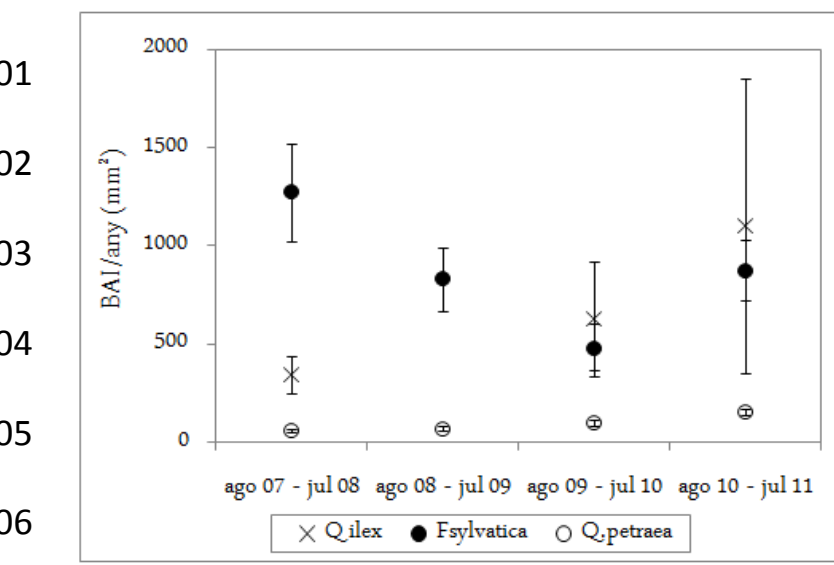

